ISSN 2449-7479

eISSN 2543-8840

amme.wne.sggw.pl

Annals of Marketing Management \& Economics

Vol. 3, No 2, 2017, 101-111

DOI 10.22630/AMME. 2017.3.2.21

\title{
DEVELOPMENT OF EDUCATIONAL MIGRATION IN UKRAINE
}

\author{
Natalia Stepaniuk \\ Rivne Region Institute of Postgraduate Pedagogical Education, Ukraine
}

\section{INTRODUCTION}

In the globalized world, the phenomenon of educational migration is getting more and more significance. Migration of high qualified experts and scholars has a significant impact on the socio-economic development of the countries. Namely, there is a positive effect on the quality of economic growth of the countries with immigration, but at the same time it leads to loss of competitive advantages for the countries of emigration.

Ukrainian migration, which started in the period of Ukrainian nation-building, has a number of peculiar features that distinguish it from the previous waves of migration. The most important feature is the change in the meaning of the word migrant - this is no longer a low-skilled worker, but a person who has high or vocational education, speaks foreign languages, can work with modern computer technologies, and can apply innovative methodologies.

In addition, there is an increase in the number of migrants among scientists (to work in research and technology centres in different countries for acquiring, improving and applying their knowledge), teaching staff (for training and career enhancement via attending lectures of the leading professors, giving author's courses), and students (for education, training, and postgraduate work).

\section{ANALYSIS OF RECENT RESEARCHES AND PUBLICATIONS}

Various aspects and problems of educational migration were studied by M. Bachynska, L. Beztelesna, L. Zhurakovska, D. Kucherenko, L. Oppeld, M. Panteleyeva, N. Poberezhna, Yu. Chekushyna, A. Shevchuk and others. 
L. Beztelesna emphasizes the idea that today the countries of the world are interested in forming the educational and qualification potential via migration primarily via involving foreign students and their future employment in the national labour markets [Beztelesna 2014].

Exploring the trends in educational migration, L. Zhurakovska highlights the idea that educational migrants, i.e. foreign students, can be considered as the most desired category of migrants, as they are usually represented by the most talented and motivated young people, willing to accept new knowledge and technologies. For the majority of developed countries, educational migration is becoming one of the means of forming the human capital which is necessary for the development of national economies; simultaneously, it is a powerful geopolitical resource used for the spread and promotion of culture and technology of the countries where the foreigners get education [Zhurakovska 2014].

A person acquiring new skills and knowledge is the main driver of economic development. Taking this into account, each country is interested in increasing the human potential. As a result, educational migration is becoming a crucial issue in the context of globalization, as D. Kucherenko states [Kucherenko and Martyniuk 2011].

In addition, the problems of educational migration are the subject of research by V. Iontsev, O. Bilyakovska, O. Malinovska. V. Iontsev defines educational migration as territorial movement from one locality (state) into another with the aim of getting education (or training) in one of the educational institutions of the locality (state). Having obtained education, a person who went to another country to study is obliged to return to the home country. However, there are cases of not returning, which are classified as "brain outflow" [Bilyakovska 2011]. O. Bilyakovska states that the purpose of educational migration is getting education and identifies the characteristic features of educational migration. They are: short-term nature, more or less clearly defined timeframe, adherence to a particular age group, voluntary nature of the movement [Bilyakovska 2011]. O. Malinovska identifies international educational migration as the movement of foreign students [Malinovska 2012].

Analysis of publications on this problem proves the urgency of the issue of educational migration, and it is still important nowadays to do the analysis of educational migration tendencies, and search for mechanisms of counteracting the transformation of Ukraine into the country of origin for educational migrants.

\section{AIM AND OBJECTIVES}

The aim of the article is to study the establishment of educational migration under the conditions of global instability, its development and impact. Global financial and economic crisis has raised a number of new questions for researchers who study educational migration processes. To determine what measures are needed to counteract the threats of mass education migration from Ukraine, first of all, it is necessary to identify the main reasons that prompted the development of such events. 


\section{BASE MATERIAL SUMMARY, OBTAINED RESULTS AND DISCCUSSION}

Globalization under the modern conditions is a dominant trend that causes significant transformations in all spheres of public life. It is important to point out not only the fact of changes, but also those effects which the global processes make on the social system in general and system of education system in particular. Globalization and development of integration processes contributed to crossing of the national borders by educational services.

Naturally determined appropriate process that enables balancing the economic, social, political and spiritual spheres of society is defined as migration. Migration (from the Latin migratio - relocation) is the movement of people across the borders of certain territories with changing the place of residence permanently or for a more or less long time. Among the varieties of migration, it is possible to distinguish educational migration, which is mostly temporary relocation done to obtain education and training outside the administrative unit of residence [Romanenko 2014].

We believe that educational migration is a socio-economic and demographic process, which represents the frequency of changing the place of residence by scientists, academic staff, students and other individuals inside the country and abroad for the purpose of temporary or permanent change of employment, career enhancement, doing research, postgraduate education, training and other reasons.

Educational mobility as a prerequisite for educational migration is based primarily on the desire of an individual to get certain education, which can be classified in terms of the desired level of qualification, professional specialization, ways of getting education and the desired result.

Let us consider the historical background of educational migration in Ukraine. In Europe, the first university was founded in Bologna (Italy) in 1119. According to the regulations of the university, professors and students of the university could be selected from the representatives of any country and any nation. Medieval universities were an international phenomenon. Moreover, according to the statutes of certain institutions, people from other countries were eligible for top positions, up to the position of the rector. In particular, a Ukrainian Yuriy Drohobych was elected as a rector of the University of Bologna in 1481.

Moreover, although most universities tried to copy the structure of the University of Bologna, there were those that offered absolutely different approaches to their institutions, for instance, in England (Oxford, Cambridge University), where mainly the representatives of the aristocracy and wealthy families studied. From Ukraine, there were children of the ruling classes, noble families and the Cossack elite.

When a part of the Ukrainian youth got an opportunity to improve their education, the public reacted to that differently. Immediately, there appeared the supporters and opponents of study abroad. Thus, young people eagerly wanted to study at universities, because people who graduated from universities in those days acquired human rights (exempt from taxes, possibility to appeal to the highest court, granted earnings in the field under those terms and conditions). The main opposition was the church, being afraid of heresy and blasphemy, or even Catholicism that the future bachelors and masters could 
bring together with education. Some people tried to interpret the foreign education issues in a way of compromise; however, the benefits of science were recognized indisputably.

In the $14^{\text {th }}-18^{\text {th }}$ centuries, immigrants from Ukraine attended the studies in almost all European universities. Many of them even graduated from two or even three institutions; besides, they showed constant dissatisfaction with what they knew.

The efforts of cultural and educational professionals aimed at strengthening the national school and science were not in vain. Kyiv Collegium (later Kyiv Mohylanska Academy), in which numerous students of European universities cooperated actively became an institute of higher education. After its foundation in 1724, at St. Petersburg Academy of Sciences, and later Academic University and Moscow University (1755), a significant part of Ukrainian youth went to study to those national institutions.

On completing the studies at foreign higher schools, almost all young scientists returned to their homeland; however, there were those who remained in the countries where they got education to become professors, deans, researchers and scientists; they took part in the European process of development of science, art and culture.

Thus, the historical retrospective is evidence that educational migration had been caused in a significant rate by regional imbalance of human resources, regional differences in living standards, uneven placement of jobs and educational institutions. A specific feature of educational migration, according to researchers, is its least harmful nature in contrast to other types of migration. The desirability of educational migration was predetermined by the income not only of the educational sector (or a particular university), but also of the economy of the country (region) that provides educational services in general. In addition, consumers of educational services are a potential workforce of corresponding qualifications [Kryvenko 2011].

Using the principles of system approach methodology, educational migration as a factor of migration system development can be described as follows. According to the systematic approach [Hrymblat 2004], a system is defined as any phenomenon, process (a set of interrelated elements) separated from the environment and interacting with it as a whole.

The latter are coordinated through relations between them to be organized into a certain structure (at the Ukrainian level - national and regional markets of education services, at the European level - European market of education services, EHEA, ERA). Being capable of self-development, the system has a semi-interpenetrating limit (openness and interconnection of regional and national migration system with the environment). The required attributes of the system are the purpose of existence and purpose of the system development (meeting the needs of population in higher education, joining the Bologna process, the EHEA, ERA by Ukraine).

The aim of the reform as defined in the Bologna Declaration is to create a single "European Higher Education Area" and "European Research Area". Implementation of "freedom of knowledge movement", formal criteria of the Bologna process, generates active international cooperation in the field of education, overcomes the barriers on the way to quality higher education, activates the mobility of students and teaching staff, is supposed to prepare young people to active life in the demographic society, ensure career and personal development. The volumes of educational migration in the countries of Bologna process are covered in the annual report on higher education in Europe [WWW 1]. 
The experts of the European expert group on educational mobility in their report "Making Learning Mobility an Opportunity for All" predict that by 2020 the number of young Europeans aged from 16 to 29 years old who will have a possibility to study abroad will have reached $50 \%$. To achieve that, each year $6 \%$ of all university students and $3.5 \%$ of students of professional schools year have to go abroad to study [WWW 2].

Involving young people with a high level of education to the labour market contributes to the accumulation of human capital, which is one of the key factors of modern economic development.

It was estimated that the increase in the duration of study for the population by a year in the long-term perspective ensures the increase in GDP by 3-6\% [OECD 2007].

In the structure of total migration flows, educational migration is predetermined by satisfying social needs in obtaining education and raising the qualification level. At the same time, educational migration can respond to a certain extent to the patterns of social and economic type of migration.

To specify the characteristic features of educational migration in Ukraine, it is necessary to identify the individual characteristics of these movements (Table 1).

The greatest danger of intellectual migration is not all Ukrainian scientists who depart from the country, really working abroad as a researcher. According to statistics, only $20 \%$ of migrants intellectual arranged by specialty within those scientific projects on which they work in Ukraine. For the most part, it is the most qualified, already known for his work abroad. The rest gets a job is not their specialty. But we should not underestimate the economic component of intellectual migration, because the majority of Ukrainian scientists important factor in the so-called welfare, decent wages, high levels of material and technical equipment of workplace and good working conditions and life.

We believe that maintaining and expanding of the reproduction of intellectual potential requires effective measures of educational and migration state policy that would be quickly adapted to the changes in the global economic environment. It is necessary to use the mechanisms which could formulate a systematic movement of intelligence, capital, and information in two mutually symmetrical directions (into Ukraine and out of Ukraine). It is necessary to strengthen the competitive advantages of the country in science, education and high technologies.

Under these conditions, export of educational services turns into a profitable economic activity, an indicator of improvement of the level and quality of education. Effective measures for effective use of scientific and educational potential as well as settling educational migration in the regions and the country in general are the following: increase of the level of funding for education and science; formation of stable relationships between educational and research activities based on projects that bring together scientists and teachers from a defined share of state and regional funding; building conditions for engaging talented young people to scientific activities; strengthening of the responsibility for ensuring decent social conditions for young professionals.

Regulation of the educational migration is done from two sides: regulation of migration and regulation of education. Regulation of migration takes place within the migration policy, which is defined as "a system of legal, financial, administrative and organizational measures of the state and non-governmental institutions related to managing the migration processes from the point of view of migration priorities, quantitative and qualita- 


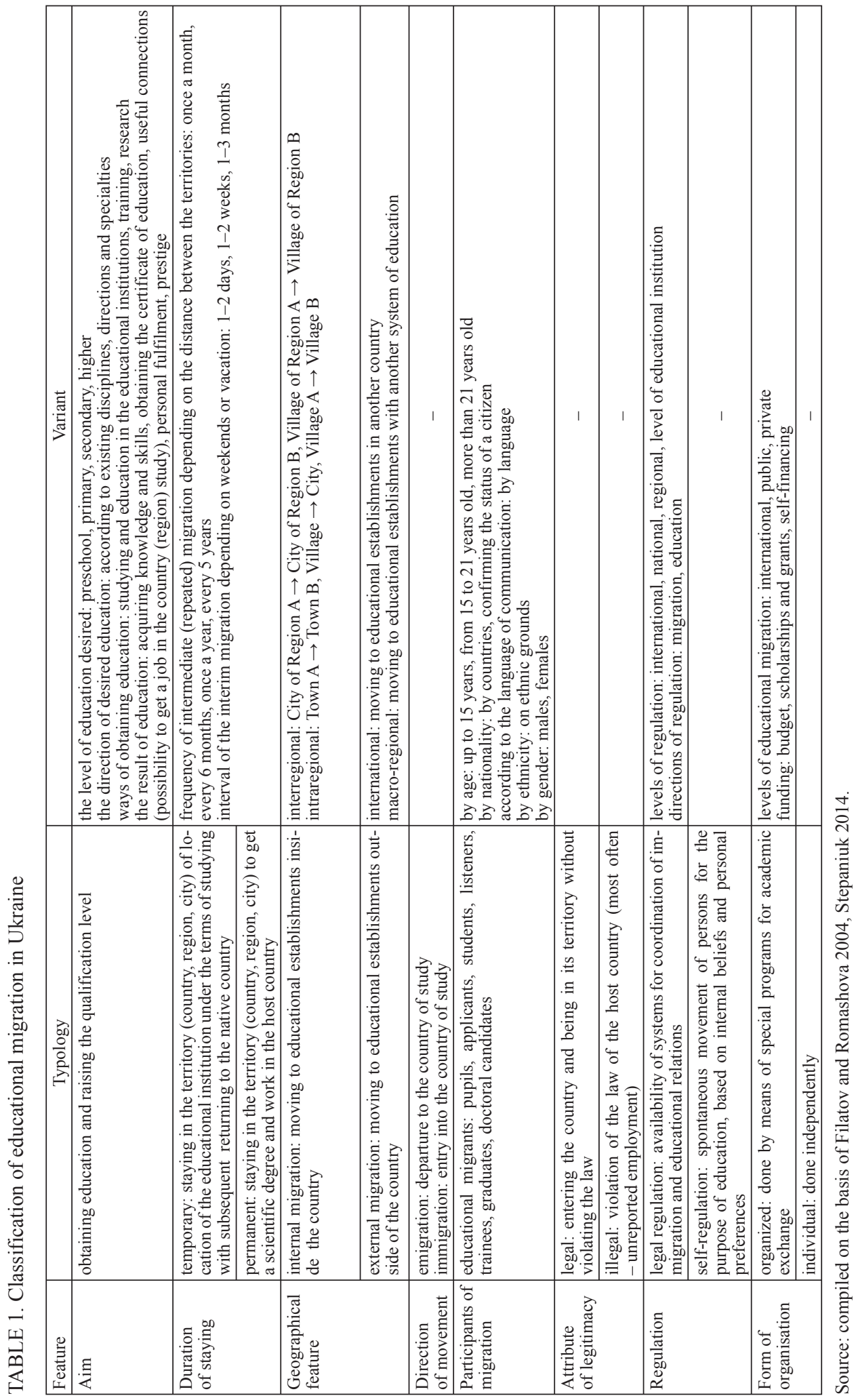


tive composition of migration flows, their social, demographic and economic structure" [Petrova 1996]. Regulation of education takes place within the educational policy, which is defined as "a set of goals, objectives, principles, programs and basic activities of education authorities, aimed at organizing the scientific and methodological support and implementing education development strategy" [Krasnyakov 2011]. However, it is important to take into account dualism of globalization in the process of developing educational strategies and implementation of educational policies. On the one hand, global processes extend the capabilities of certain countries in the field of using intellectual resources; on the other hand, globalization intensifies competitive struggle for educational product, involves rivalry and is managed with commercial and competitive approaches. This is a threat to the countries with low and middle levels of income.

The development level of each country is measured by a number of indicators, including economic, social, demographic and other ones. One of the problems that arise in European countries today is a demographic problem. The natural reduction of population is a crucial problem of not only demographic, but also social and economic value, since it leads to losses of potentially employable population. In some European countries, natural reduction in population is partially compensated with the immigration growth, whereas in Ukraine the tendency of migration and natural movement of population which got established in the years of 1990-2015, has become a threat to the state from the point of view of not only demographic but also economical aspect.

The main factors that promote to increase migration processes in Ukraine include:

- low wages;

- instability of the Ukrainian economy;

- lack of jobs for people (mostly in small towns and villages);

- a good social support in countries where Ukrainians migrate;

- political instability in the country;

- loss of hope for a better life in Ukraine for themselves and their children;

- lack of conditions for self-fulfilment (it causes the brain drain potential).

For example, the Union of Soviet Socialist Republics owned 25\% of the scientific potential of the world. This is largely ensured him the status of "superpower". In the early 1990s in the states of the former Soviet Union because of the destruction of the once unified system development science research institutions in each country took place in extremely complex crisis collapse of the intellectual community, which gave the opportunity to exchange experiences and scientific and important information.

Due to the natural movement of 2015 there was a reduction in the population of Ukraine by 166.4 thousand of people. Within the period of independence of Ukraine, the natural reduction in population had reached its historically highest rate in 2000, amounting to 373 thousand of people. In 2015, reduction of population due to natural movement, compared to the corresponding rate in 2000 , decreased by almost a half. However, starting from 2011 (162 thousand of people), there has been a negative tendency to the growth if population reduction (in 2015, there was an increase in population reduction by 4.4 thousand of people (2.7\%) as compared to the level of the year 2011); compared to 1991 , when there were the lowest (39.1 thousand of people) rate of natural population reduction during the period of independence of Ukraine, the rate of natural reduction of population in 2015 was almost 4.3 times higher. 
We studied the analysis of the data regarding the changes in volumes of involving the age groups of population in the labour market to identify the following tendencies:

- increase in the share of the population aged 15-19 years old involved in the labour force. Thus, starting from 1990, the proportion of working teenagers had grown by more than three times (from 10\% of the total population aged 15-19 years old in 1990 to 27 and $35 \%$ correspondingly of involving female and male population in the labour market in 2020);

- increase in the share of population aged over 60 years old involved in the labour force. In particular, this proportion over the last 25-30 years has increased from 15.5 and $31.5 \%$ of female and male population in 1990 respectively to 35 and $38.9 \%$ in 2020 according to the corresponding factors);

- reduction in the involvement of population aged from 24 to 50 years old to the labour market that negatively affects employees, in particular, by strengthening the pension fund burden on their wages.

Prerequisites for such trends are primarily the socio-economic factors that do not encourage the population to support the schemes of expanded reproduction, causing the migration movement.

As an indicator of not only social protection of the population in the country, but also an indicator of the cost of labour, the employee benefits related to the performance of their job duties, are subject to consideration, first of all, from a macroeconomic point of view, since the labour market determines the size and dynamics of wages and other employee benefits.

TABLE 2. Minimum wages in the EU Member States and Ukraine, as of January 2015

\begin{tabular}{|c|c|c|c|}
\hline \multirow[b]{2}{*}{ Country } & \multicolumn{2}{|c|}{ The minimum wage as of January 2015} & \multirow[b]{2}{*}{$\begin{array}{c}\text { Migration of Ukraine in } \\
2015 \\
\text { (people) }\end{array}$} \\
\hline & EUR per month & $\begin{array}{l}\text { the number of times } \\
\text { the excess minimum wage } \\
\text { in Ukraine }\end{array}$ & \\
\hline Bulgaria & 184 & 2.9 & 25 \\
\hline Romania & 218 & 3.5 & 9 \\
\hline Lithuania & 300 & 4.8 & 64 \\
\hline Czech Republic & 332 & 5.3 & 89 \\
\hline Hungary & 335 & 5.3 & 816 \\
\hline Slovakia & 380 & 6.0 & 19 \\
\hline Poland & 410 & 6.5 & 88 \\
\hline Portugal & 589 & 9.3 & 11 \\
\hline Greece & 684 & 10.9 & - \\
\hline Spain & 757 & 12.0 & 87 \\
\hline United Kingdom & 1379 & 21.9 & - \\
\hline Germany & 1428 & 22.7 & 795 \\
\hline Belgium & 1502 & 23.8 & - \\
\hline Netherlands & 1502 & 23.8 & 13 \\
\hline Luxembourg & 1923 & 30.5 & - \\
\hline Ukraine & 63 & - & - \\
\hline
\end{tabular}

Source: composed according to data of Eurostat [WWW 3], the NBU [WWW 4], article 8 of the Law on State Budget of Ukraine for the year of 2015. 
The minimum wages approved on 1 January 2015 in Ukraine was almost three times lower than the lowest minimum wage in the EU countries (Bulgaria) and more than 30 times lower (Table 2) than the highest minimum wage in the EU countries (Luxembourg).

One of the reasons for this situation is the low level of minimum wages. The nominal minimum wages in Ukraine starting from 1 September 2015 is 1,378 UAH; that is $158.57 \%$ more than the nominal minimum wage established on 1 January 2010. Instead, the minimum wages presented in foreign currency (EUR, USD) as calculated at the official rate of the NBU to date tends to decrease: as of 1 September, 2015 there was a decrease in minimum wages by 25.75 and $21.78 \%$ respectively from the minimum wages established on 1 January 2010 presented in euro and American dollars respectively [Stepaniuk 2016].

The facts mentioned above indicate that wages in Ukraine has lost its reproductive function. This leads, in particular, to the migration of population, including educational migration. Therefore, our study proves worsening of the situation in educational migration flows. More and more highly educated people seek to realize their potential in other countries to get higher salaries.

\section{CONCLUSIONS}

In Ukraine, the development of educational migration started a long time ago. Today, in the context of globalization, it is increasingly developing. In Ukraine, an important factor that influenced these processes is the enhancement of economic crisis and the decline of national system of education.

The intentions of young people to get temporarily involved in the international educational and scientific space are an effective channel of realization of intellectual potential and self-assertion. Coming back, they bring to Ukraine a new intellectual product, new knowledge and technologies. However, it frequently happens that the major part of this group of migrants does not want to realize their intellectual potential in their own country, and they go abroad for labour migration.

We believe that the situation can be changed if effective immigration policy includes the interests of economic development of the country on the basis of the knowledge acquired by educational migrants. The ultimate goal should be not the termination of migration, as it is impossible in the context of globalization, but the introduction of an effective mechanism of free circulation of migrants, including transformation of irreversible emigration into a temporary one.

\section{REFERENCES}

BEZTELESNA L., 2014. Internationalization of high education under the conditions of international migration as a medium of human potential, Herald of Khmelnytsky National University $3,254-257$.

BILYAKOVSKA O.V., 2011. Educational migration of Ukrainians to Poland: socio-psychological aspect, (in:) Socio-economic and ethno-cultural consequences of migration for Ukraine: 
Collection of materials of research and training conference, Kyiv, 27 September 2011, 231-237.

FILATOV V.M., ROMASHOVA Y.V., 2014. Специфічні ознаки освітньої міграції та її місце в структурі міграційних потоків (Specific features of educational migration and its place in the structure of migration flows) [in Ukrainian], Efficient Economy 2, 331.556 : 332.1(477), retrieved from http://www.economy.nayka.com.ua/?op=1\&z=2785.

HRYMBLAT S., VORONOV M., 2004. Strategy of Personnel Management (View from the Future to the Future) [in Ukrainian], NHyka-Tsentr.

KRASNYAKOV E., 2011. State educational policy: essence of the concept, systematic nature, historical and political aspects, Theoretical Journal of Public Policy 20, 21-24.

KRYVENKO Y.I., 2011. Socio-philosophical analysis of the causes and mechanisms of migration of human resources in postmodern society, Scientific Bulletin of Chernivtsi University, Collection of Scientific Works, Philosophy 561-562, 217-221.

KUCHERENKO D., MARTYNIUK O., 2011. Strategies of educational systems in the countries of the world, NCI DSZU.

Law on State Budget of Ukraine for the year of 2015 as of 28 December 2014. No 80-VIII, retrieved from http://zakon5.rada.gov.ua/laws/show/80-9/print1446127105290717.

MALINOVSKA O.A., 2012. Diversification of population in Ukraine under the influence of international migration: a challenge and ways to respond: analytical report, National Institute of Strategic Research, NISS.

OECD, World Bank, 2007. Cross-border Tertiary Education: A Way towards Capacity Development.

PETROVA T.P., 1996. The concept of state migration policy of Ukraine: target orientation and basic directions, Scientific Research Centre for the Employment Issues and Job Market.

ROMANENKO I.O., 2014. Causes and consequences of intellectual labour migration. Actual questions of financial and economic development of the country and regions, Collection of abstracts of scientific papers of the International research and training conference "New Economy", 113-117.

STEPANIUK N.A., 2014. Глобальна фінансова нестабільність: реалії та перспективи (Global financial instability: realities and prospects) [in Ukrainian], Efficient Economy 1, retrieved from http://www.economy.nayka.com.ua/?op=1\&z=2697 [accessed: 01.03.2017].

STEPANIUK N.A., 2016. Characteristics of migration processes with manifestations of crisis. Economy and management of national economy: state, trends and prospects. Materials of the Third International Scientific Conference, Odesa, 23-24 June 2016, ONEU, 79-81.

WWW 1. Making learning mobility an opportunity for all. Report of High Level Expert Forum on Mobility, retrieved from http://ec.europa.eu/education/doc/2015/ mobilityreport_en.pdf [accessed: 01.03.2017].

WWW 2. Uriadovyi portal, 2016, retrieved from http://www.kmu.gov.ua/control/ [accessed: 01.03.2017].

WWW 3. Monthly minimum wages in euro varied by 1 to 10 across the EU in January 2015, Eurostat, retrieved from http://ec.europa.eu/eurostat/documents/2995521/6652357/326022015AP-EN.pdf/42097ff5-231b-4116-b0cf-8a28ca316f84 [accessed: 01.03.2017].

WWW 4. Official exchange rate of hryvnia to foreign currencies, National Bank of Ukraine, retrieved from http://www.bank.gov.ua/control/uk/curmetal/detail/currency?period=daily [accessed: 01.03.2017].

ZHURAKOVSKA L., 2014. Trends of the educational migration in the context of globalization of economic development, Demography and Social Economy 1 (21), 233-242. 
Summary. The article studies the historical development of educational migration processes in Ukraine. It processes the classification of educational migration in view of global instability and manifestations of the crisis. It also suggests measures that should be implemented to prevent significant educational immigration from Ukraine. It also determines that the prerequisite for the educational migration is the desire of an individual to get certain education, which can be classified in terms of desired level of qualification, professional specialization, directions, methods and ways of getting education and the desired result. It is noted that a specific feature of educational migration is its impact not only on the profitability of the educational sector (or a particular university), but also on the economy of the country (region) that provides educational services in general. In addition, the consumers of educational services are a potential workforce of corresponding qualifications. In order to define characteristic features of educational migration from Ukraine, it was necessary to identify individual characteristics of such transferences; that is why classification of educational migration was done in view of global instability and manifestations of the crisis. To maintain and expand the reproduction of intellectual potential, it was suggested to use effective measures of educational and migration policy that would quickly adapt to the changes in the global economic environment. It is necessary to apply the mechanisms which could establish systematic movement of intelligence, capital, and information in two mutually symmetrical directions (into Ukraine and out of Ukraine). It is necessary to strengthen the competitive advantages of Ukraine in science, education and high technologies.

Key words: educational migration, economy, immigration, emigration, educational migrants, human capital, movement of intelligence, globalization

JEL: F22, F63

Corresponding author: Natalia Stepaniuk, Rivne Region Institute of Postgraduate Pedagogical Education, Ukraine, e-mail: stepanuk@ua.fm 